\title{
CERTAIN ASPECTS OF CHINESE RECONSTRUCTION
}

\author{
By Rev. Arthur H. Smith, LL.D., \\ Author of "Chinese Characteristics," Tientsin, China.
}

It is a well-known and a very instructive fact that for the last eighteen years, China and the Chinese have increasingly monopolized the attention of the rest of mankind to an extent which finds no parallel elsewhere. This is not merely because-as we are so often reminded-China is the oldest, the most populous, and by far the most homogeneous empire now in existence, but because in a great variety of ways, China and the Chinese from being one of the most secluded of peoples, have gradually, unconsciously, and without any desire on their own part become involved in intimate relationship with practically all the leading nations of the world. The acquaintance with Far Eastern affairs on the part of Occidental peoples as a whole is of much too general and incidental a character to be described as knowledge. ${ }^{1}$ Chinese history has been thought of as inherently interminable, monotonous, incomprehensible and arid. Although the same relations of cause and effect elsewhere perceived to be invariable in human affairs obtain in the evolution of China, it has until recently been assumed that the causes were inherently obscure, and the effects for the most part but slightly related to Western civilization. There have always been, of course, an instructed few who knew better, and who did their best according to their lights to make others recognize the truth, but their efforts met with but a limited success. The dramatic and swift-moving struggle between "little Japan" and "big China" in the years I894-5 immediately attracted the attention of the world, and held it to the end. Never was a struggle more inevitable than this one, yet seldom has such a contest been so unanticipated, and its outcome so spectacular. This was not merely because the world at large knew too little of the real relations between China and Japan to serve as a basis for an intelli-

\footnotetext{
1The chapter appended has been written during the exigencies of rallway travel, without access to books, or to the copious clippings and memoranda which under normal circumstances would have been available. It is rather a rough charcoal sketch than an essay.
} 
gent opinion, but also because nearly all things Chinese were wrapped in a more or less impenetrable haze, which made such knowledge of China as may be had of other countries hopeless of attainment. China was beaten, that was certain, although the greater part of the empire was never really aware of the fact, and many millions of Chinese seemed to suppose that the struggle with Japan was a "northern war," under the especial patronage of Lord $\mathrm{Li}$ Hung-Chang, and had no important relations to the rest of the "empire." There was, perhaps, also not a little satisfaction that "little Japan" had been balked of the most vital part of her conquests, through the collusion of France, Germany, and Russia, who demanded in the interests of permanent peace and the welfare of mankind that Japan renounce her hold upon the Liao-tung peninsula, and be content with Formosa and a cash indemnity. Ten years later the inevitable consequences of this action became obvious to the whole world. By that time Japan had secured Korea, had once more captured the little peninsula and a large part of Manchuria also, the remainder being largely dominated by Russia, who came to an understanding with her alert and invincible enemy, the real struggle being postponed to the uncertain future. And these two powers once in military, railway, and commercial possession have promised to evacuate Manchuria, as the Chinese phrase goes, "when iron trees bear flowers, and in the donkey year." The course of events in China was equally dramatic and surprising. For more than two years the empire was stunned, hopeless and helpless. The return to Peking in triumph from a long exile in Sian-fu the ancient and historic capital of China, of the late Grand Empress Dowager in January, 1902, seemed to promise a new lease of power to the Manchus, whose fortunes had been in grave doubt. She returned to power with a distinctly clarified vision. One by one each of the important reforms of His Majesty Kuang $\mathrm{Hsu}$ was adopted by her, as the time was considered ripe. Of these, by far the most important was the displacing (September, 1905) of the ancient system of education by "Western Learning," a compound term of unknown but far-reaching significance. Millions of Chinese scholars were thus automatically reduced to the level of brevet fossils, with no possibility of ever competing successfully for the new mysterious degrees. These mighty changes directly affected some millions of Chinese scholars and 
students, and together undoubtedly constitute the greatest intellectual revolution in the history of mankind. But in so vast a country as China, where the impulse to stick by the old ways is overwhelming, it was inevitable that in most parts of most provinces things went on much as before.

The decree extending education to Chinese women (1907) was another landmark of progress, though its full effects can scarcely be realized for a century or more. The dispatch to Western lands of Imperial Commissions of Inquiry in regard to "Constitutional Government" (I905) was a skilful effort on the part of the Empress Dowager to withdraw the attention of the Chinese (especially in the southern province of Kuang-tung, Canton) from present ills, by contemplation of a free gift to the people from the Throne of a share in their own government. As the ancient sages and the sacred classics had much to say about "the People" (who are the "Root" of a country, Heaven thinking as the people think, etc.,) this, while a radical innovation, had, like much else, the air of a sudden return to first principles. There can be no doubt that the intention of the Throne was to tide over present dangers by throwing two or three empty tubs to the whale Demos. One of these was the "Provincial Council," one was "Local Self-Government," and the third and by far the most important, the promised "National Parliament," to meet in I9I7. Experts in constitutional law have minutely analyzed the voluminous documents issued by the government, explaining the purpose and the explicit limitations of this imperial gift. It was a formal grant of the right of assembly, of discussion, and of petition, under careful precautions to guard against any assumption of a power to legislate, or to demand concessions from the Throne. In its lower ranges Chinese society has always been in theory frankly democratic-probably quite as much so as that of any Occidental land. It is only at the county (or hsien) the smallest sub-division of independent Chinese rule, that the oligarchical official superstructure imposed upon the basal democracy, begins. But theoretical democracy in China, as elsewhere, is so greatly modified in practices by the presence and the influence of wealth, a literary degree, connection with important families, or exceptional individual abilities, that the composition of these forces is frequently anything but really democratic.

To the "Local Self-Government" plan the Chinese are there- 
fore inherently predisposed. But practically much less seems to have been made of it than might have been expected. This was not improbably due to the numerous points of friction between local self-government bodies, small, isolated and inexperienced, and the county magistrates with whose prerogatives and perquisites there would be almost inevitable interference. Nothing but extended experience, mutual co-operation, and above all, time, is needed to enable Chinese bodies for local self-government when duly authorized and recognized from making themselves universally felt.

The progress made by the "Provincial Councils" in the two short seasons in which they have had opportunity to find themselves and their place is altogether unique in Chinese history. These bodies be it remembered were never intended as other than harmless blow-holes and escape-valves for popular effervescence, with no real power and, indeed, with no functions of importance. Those who knew most about China recognized the inherent futility of elaborately constituting a complicated body with a totally uncoordinated membership merely to discuss matters of importance, but over which they could exert no practical influence whatever. The essential sub-stratum of Chinese democracy had now, however, an opportunity of asserting itself. Never before had gentry and commoners been summoned to deliberate, not, let it be remembered, to decide, in regard to public affairs-especially taxation-in the virtual presence of the Governor, a mighty official hitherto immune to popular suggestion much more to criticism. But every Provincial Council took itself most seriously. It did not indeed know its business, nor how to do it. But it listened to the primary lessons in procedure given by the Governor's deputy, and took careful note that the matter of public revenues was included in their somewhat narrow horizon- "What revenues do you want for the coming year?" the delegates in their innocence and verdancy inquired. When the sum was named, they at once proceeded to ask further: "What was done with the amount produced by last year's taxation?" In China nobody "from below" ever ventures to make inquiries like this. It is the business of the officials to levy the taxes, and of the people to pay them-"theirs not to reason why."

Under these novel and irritating conditions, and there were others aplenty, the Governors would gladly have swept the whole 
set of "Councils" into extinction. But having been appointed by the Throne to do a specific act, no matter how futile, it was beyond the power of any Governor to deny or to ignore the right of the delegates to inquire. But more truly than in the Arabian tale the Afrite had actually emerged from the bottle officially uncorked, there he was large and threatening, and ever growing larger and more threatening. For behind all this "Constitutional Government" foam and sound, there was the great sea, the implicit rights of the people to be heard from and to be regarded, a right long ignored but soon to become more and more explicit and insistent. If the evolution of the Provincial Councils, albeit in very different ways and degrees from non-existence into "triumphant democracy" was rapid and striking, that of the National Assembly in Peking, the germ of the distant Parliament, was far more so. Half of this body was directly nominated by the Throne and must, of course, have been considered thoroughly safe custodians of the interests of the officials strongly entrenched in hereditary power. The other half of the body were appointed by the Governors of provinces from nominees whose names were sent in by the Provincial Councils principally, if not entirely, from among their own number. In this case also it is certain that only the safest candidates would have been appointed. The assembly was presided over by a Manchu hereditary Prince, an additional guaranty of conservatism. And yet the National Assembly, so constituted and limited in the range of its action, by lack of knowledge, lack of experiences, and the inherent difficulties of their position, succeeded during the three months of their session in achieving results of a most surprising character. They learned almost at once to take the opposition side and to act together. They forced the hands of the Prince Regent and virtually compelled him to shorten by some years the date of the longed-for Parliament, which was now put down for 1913. They freely criticized the heads of the leading departments of the government, and they even went so far as to impeach the semi-sacred Grand Council itself, as being an inefficient and an irresponsible nuisance. No such attack on vested rights and prescriptive privilege had ever, we may suppose, been made in Peking before. The insistent demand for a budget and for explicit statements of revenue and expenditure brought clearly to light the existing financial chaos, 
and plunged the assembly into a morass and a jungle of accounts and statistics from which, after more than forty days of arduous work, they emerged, to say the least, with more credit than did the Board of Revenue. The Prince Regent not only did not summarily dismiss the assembly as the late Grand Empress Dowager would assuredly have done, but temporized with them, and added ten more days to their session.

This first meeting of the National Assembly in the autumn and winter of rglo must be regarded as of prime importance as an initial flight of parliamentary petrels trying their wings in stormy gales. Every lesson here learned will be most valuable in the turbulent days which are yet to come, when China is more or less blindly attempting to solve anew the age-long and world-wide questions which even twentieth century democracy finds as perplexing and as insistent as ever they have been in the past-nay, much more so. How can ancient China sailing, with its clumsy junk-of-state, under a "republican" flag navigate such dangerous and uncharted seas?

Probably few Chinese have ever heard the name of Fisher Ames, one of the delegates to the Constitutional Convention which adopted the basis of the American Union. Yet his sage remark is strangely applicable to China to-day, as it was in the thirteen colonies in I789. "A monarchy," he is reported to have said, "is a stoutly built ship; yet it sometimes strikes a rock and goes down. A republic is like a raft, it never sinks, but then your feet are always in the water."

For several months China has been once more thrown into convulsion and in an altogether novel manner. Owing to certain peculiar teachings of their most revered sages, Confucius and Mencius, the Chinese have always cherished and exercised what has been termed "the right of rebellion." When the ruler has obviously lost "the decree of heaven," which alone authenticates him as ruler, then may the Superior Man, who is himself taught of heaven, resist and depose that ruler; thus the Chinese have always been specialists and experts in the art of rebellion, insomuch that it is estimated that there have been fifty first-class rebellions in the past two thousand years, as well as minor ones quite beyond count. But no one of them bears any real resemblance to the present uprising, which not only potentially and prospectively pervades every 
part of the empire, but is even more really felt by Chinese living abroad in every land and under every sky where Chinese emigrants make their home. Each passing week has showed how largely China's revolution, not rebellion,- the first in more than two thousand two hundred years of turbulent history-is at bottom a race question. It is now two hundred and sixty-seven years since the Manchus, not uninvited and certainly not at all reluctantly, took charge of the Chinese Empire. In the slow progress of the domination of so vast an area multitudes of Chinese were killed, and many more died of hunger, fright, disease, or committed suicide. All these are familiar phenomena in China and were only such as the ending and the beginning of other dynasties as well as the latest have always witnessed. But in the new national selfconsciousness, the ancient memories of these wrongs have, like unquiet ghosts, risen from the dead to irritate the Chinese and to terrify the Manchus. The latter cannot be more than a few millions in number (how many in the absence of any census it is impossible to say), and with all China once aroused against them as never before, their position becomes precarious and untenable. Other aspects of the race problem in China are found in the friction, sure to increase, between Chinese and Mongols, Chinese and Mohammedans (who have been for much more than-a thousand years a mechanical and not a chemical mixture with the Chinese), Chinese and the Thibetans, and particularly Chinese and the "aboriginal" tribes who form a large part of the population of some of the southwestern provinces, as Kueichew and Yunnan. They, too, have begun to awaken to self-consciousness, and can no longer be governed by the ancient methods of cajolery, bribery, and brutality.

Surely no problems of the coming China are more intricate, more exigent, more perilous than those relating to the numerous and diverse races of the vast territories of the Chinese Empire. The Chinese have always believed their theory of government to be perfect-it failed only in practice. Ages of corruption not unlike that of Turkey have necessitated ages of misrule and oppression, and have brought to pass the unhappy and until lately almost hopeless China with which we are too familiar. Can China under a so-called republic effect a radical cure of these hideous cancers and gangrene, which have been eating out the life of a great 
people? The wonderful success in arousing not merely a national consciousness, but what is far more difficult, the national conscience in a life and death struggle with opium, against odds almost overwhelming, show what unanticipated and even unimaginable reserves of moral power are available in China.

Far more than most peoples in history the Chinese have always had ingrained in their moral race-fiber deep reverence for that righteousness which is one of their Five Constant Virtues. Their long history is studded with shining examples of its practice, even in times of darkness and despotism. New light has come to China from the West, from the past, and from above. A new public sentiment has begun to crystallize in China, and there is every indication that it may eventually be as resistless as a tidal wave. This may not, will not, come suddenly, but it will come, and it will be at once the bulwark and the backbone of the new nation. At the opening of a year certain to be full of surprises, when nothing can clearly be foreseen as to the specific turn of events in China one can only say that regarded from any point of view it is one of the most interesting, and one of the most importants events of contemporaneous history that the oldest and most populous of empires should throw its past into the melting pot in order to gain a bright and a glorious future. In this great struggle China deserves and will have the sympathies of the great republic of the West, whose problems are so widely different, and yet in essence so alike. A new China will help to make a new Asia, and will both directly and indirectly influence the whole world. 